\title{
Cyclin D1 is a nuclear protein required for cell cycle progression in $\mathbf{G}_{1}$
}

\author{
Véronique Baldin, Jiri Lukas, María Jesús Marcote, Michele Pagano ${ }^{1}$, and Giulio Draetta ${ }^{1}$ \\ Differentiation Programme, European Molecular Biology Laboratory, D-6900 Heidelberg, Germany
}

\begin{abstract}
A cascade of events is triggered upon the addition of growth factor to quiescent mammalian cells, which ultimately restarts proliferation by inducing the transition from $G_{0} / G_{1}$ to S-phase. We have studied cyclin $D 1$, a putative $G_{1}$ cyclin, in normal diploid human fibroblasts. Cyclin D1 accumulated and reached a maximum level before S-phase upon the addition of serum to quiescent cells. The protein was localized to the nucleus, and it disappeared from the nucleus as cells proceeded into S-phase. Microinjection of anti-cyclin D1 antibodies or antisense plasmid prevented cells from entering S-phase, and the kinetics of inhibition showed that cyclin D1 is required at a point in the cell cycle earlier than cyclin A. These results demonstrate that cyclin D1 is a critical target of proliferative signals in $\mathbf{G}_{1}$.
\end{abstract}

[Key Words: Cyclin D1; cell cycle; nuclear protein; cell proliferation]

Received November 13, 1992; revised version accepted February 8, 1993.

The availability of growth factors and nutrients and the surrounding environment of any cell in a multicellular eukaryote regulate its proliferative potential (Pardee 1989). Signals transduced from the extracellular environment impinge on the cell cycle control machinery and determine whether a cell should proceed through the cell cycle or become quiescent. Because these controls are defective in cancer cells, it is crucial to understand the molecular reactions involved before devising novel strategies for cancer treatment.

A family of serine/threonine protein kinases, the cyclin-dependent kinases (Cdks), have been described recently. These Cdks appear to have a role in controlling progression through the cell cycle (for review, see Pines and Hunter 1991). The prototype cyclin-dependent protein kinase, Cdc2, is a regulator of mitosis in all eukaryotic cells. A complex of $\mathrm{Cdc} 2$ and its regulatory subunit cyclin $B$ is activated specifically before mitosis and phosphorylates key mitotic proteins (for review, see Draetta 1991; Nigg 1991).

Although much is known about the regulation of entry into mitosis, our knowledge of the molecular mechanisms that control progression through other cell cycle stages is limited mostly to findings in yeast. In Schizosaccharomyces pombe the Cdc2 kinase is required for progression into both S-phase and mitosis /for review, see Forsburg and Nurse 1991). In Saccharomyces cerevisiae, it has been demonstrated that $\mathrm{Cdc} 28$ (the $S$. cerevisiae homolog of $\mathrm{Cdc} 2$ |, through the association with distinct cyclins, activates entry into S-phase and into mitosis (Hadwiger et al. 1989; Wittemberg et al. 1990;

${ }^{1}$ Present address: Mitotix, Building 600, Cambridge, Massachusetts 02139 USA.
Ghiara et al. 1991; Surana et al. 1991). In contrast, several findings suggested that the mammalian homolog of $\mathrm{Cdc} 2$ is only involved in controlling entry into mitosis (Riabowol et al. 1989; Th'ng et al. 1990; Hamaguchi et al. 1992; Matsushime et al. 1992; Xiong et al. 1992; Pagano et al. 1993). Recently, in human, mouse, Drosophila, and Xenopus cells, novel proteins sharing structural similarities to $\mathrm{Cdc} 2$ have been identified that are likely candidates for cell cycle kinases acting at stages other than the $\mathrm{G}_{2} / \mathrm{M}$ transition (Elledge and Spottswood 1991; Ninomiya-Tsuji et al. 1991; Paris et al. 1991; Tsai et al. 1991; Meyerson et al. 1992; Okuda et al. 1992).

The regulatory subunits of these kinases, the cyclins, were identified initially in marine invertebrates as proteins that undergo periodic accumulation during the cell cycle (Evans et al. 1983; Swenson et al. 1986). They were then demonstrated to be required for cell cycle progression in these and other organisms (Swenson et al. 1986; Minshull et al. 1989; Murray and Kirschner 1989; Girard et al. 1991; Pagano et al. 1992b; Zindy et al. 1992) and to associate with Cdc2 (Booher et al. 1989; Draetta et al. 1989; Labbé et al. 1989; Meijer et al. 1989; Pines and Hunter 1989; Gautier et al. 1990; Minshull et al. 1990). After the initial isolation of cyclins A and B in humans (Pines and Hunter 1989; Wang et al. 1990), novel human cyclins (C, D, E) were identified (Koff et al. 1991; Lew et al. 1991; Matsushime et al. 1991; Motokura et al. 1991; Xiong et al. 1991), and a role during the $\mathrm{G}_{1}$ or S-phase has been hypothesized for $\mathrm{D}$ and $\mathrm{E}$ cyclins (Matsushime et al. 1991; Dulic et al. 1992; Koff et al. 1992; Lees et al. 1992). Cyclins D are only distantly related to other cyclins. Cyclin D1 is a most intriguing protein, as it was found that cyclin Dl mRNA is overexpressed in parathyroid adenoma (Motokura et al. 1991), in centrocytic lym- 
phoma (Rosenberg et al. 1991), in breast and squamous cell carcinomas (Lammie et al. 1991), and in esophageal carcinomas (Jiang et al. 1992). The overexpression in tumors suggests that cyclin D1 is involved in the process leading to transformation. Two additional cDNAs coding for proteins highly related to cyclin Dl were isolated from both mouse (Matsushime et al. 1991; Kiyokawa et al. 1992) and human cells (Inaba et al. 1992; Xiong et al. 1992). It was shown that the D-type cyclin mRNAs have a distinctive tissue-specific expression. In particular, cyclin D1 mRNA is expressed in a large number of tissues, with the exception of normal lymphoid and myeloid cells (Withers et al. 1991; Inaba et al. 1992). Cyclin D2 mRNA expression was found to be highest in sarcomas and in T lymphocytes (Matsushime et al. 1991; Inaba et al. 1992; Won et al. 1992), whereas cyclin D3 is widely expressed, but at particularly high level in leukemia cells (Inaba et al. 1992). In mouse macrophages, cyclin D1 associates with a Cdc2-related protein and becomes phosphorylated during $G_{1}$ (Matsushime et al. 1991). The major $34-\mathrm{kD}$ subunit associated with these cyclins in both macrophages and lymphocytes is PSK-J3 (Cdk4) (Matsushime et al. 1992), the product of a gene identified previously by cross-hybridization with oligonucleotide probes derived from highly conserved coding regions of the protein kinase family (Hanks 1987). In addition to Cdk4, Cdk2 and CdK5 are associated with cyclin D1 in human fibroblasts (Xiong et al. 1992). Whether these complexes are specifically activated during $G_{1}$ is not known, but it has been shown that recombinant complexes of Cdk4 and D cyclins are able to phosphorylate the retinoblastoma gene product, $\mathrm{pRb}$, a negative growth regulator whose phosphorylation is necessary for the $\mathrm{G}_{1} / \mathrm{S}$ transition (Matsushime et al. 1992).

We decided to investigate the role of cyclin D1 in human fibroblasts stimulated to reenter the cell cycle, specifically trying to understand whether in analogy to mitotic cyclins, cyclin D1 plays an activating role in the cell cycle. We found that cyclin D1 appeared in the nu- cleus as cells were stimulated to enter the cell cycle by serum addition and that it disappeared as cells entered S-phase. Microinjection of antibodies or antisense plasmid to cyclin Dl prevented cells from entering S-phase. These experiments demonstrate that cyclin Dl is an activator of cell cycle progression and that it may be regulated in a similar fashion to mitotic cyclins.

\section{Results}

\section{Cyclin D1 in human lung fibroblasts}

Using affinity-purified antibodies generated against recombinant cyclin D1 (see Materials and methods), a $M_{\mathrm{r}}$ 35,000 band was detected in immunoblots of extracts from HeLa cells or human lung fibroblast (IMR90) cells (Fig. 1A, lanes 1, 2). The protein was expressed in much greater amounts in the fibroblasts than in HeLa cells (cf. lanes 1 and 2). In the fibroblasts, after immunoprecipitation, a band of similar relative molecular mass was detected by immunoblotting (Fig. 1A, lane 4). When specific antibodies were depleted by preadsorption on cyclin Dl-Sepharose, the $35-\mathrm{kD}$ protein could not be detected (Fig. 1A, lane 6). To confirm the identity of the protein, we performed immunoprecipitations from cells metabolically labeled with $\left[{ }^{35} \mathrm{~S}\right]$ methionine. A protein of approximately $M_{\mathrm{r}} 35,000$ was identified (Fig. 1B, lane 2). The band was cut from the gel and subjected to V8-protease peptide mapping, and its digestion pattern was compared with the one of in vitro-translated ${ }^{35} \mathrm{~S}$-labeled human cyclin D1 (Fig. 1C). The two maps were identical, demonstrating that the protein recognized by our antibodies was authentic cyclin D1.

The anti-cyclin D1 antibodies also recognized recombinant human cyclin D2, but not cyclin D3 (data not shown). In the human fibroblasts neither cyclin D2 nor cyclin D3 were detected by either immunoblotting or immunoprecipitation, with our antibodies or with a specific anti-cyclin D3 antiserum (gift of Y. Xiong, Cold
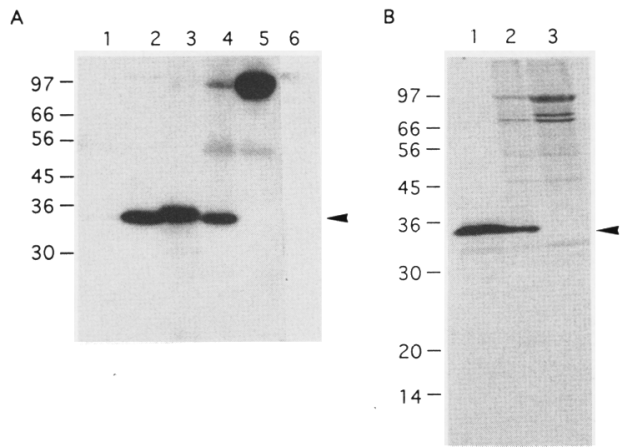

C

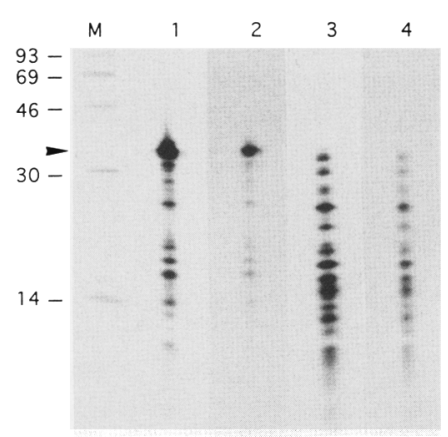

Figure 1. Characterization of anti-cyclin D1 antibodies. (A) Immunoblot. (Lane 1) HeLa extract $(100 \mu \mathrm{g})$; (lane 2) human fibroblast extract $(100 \mu g)$; (lane 3 ) recombinant human cyclin D1 (50 ng); (lane 4) immunoprecipitation (human fibroblast extract) with affinity-purified anti-cyclin D1; (lane 5) immunoprecipitation (human fibroblast extract) with normal rabbit serum; (lane 6) immunoprecipitation (human fibroblast extract) with affinity-purified anti-cyclin D1 preadsorbed on cyclin D1-Sepharose. The entire filter was blotted with affinity-purified anti-cyclin Dl.

(B) Immunoprecipitation from $\left[{ }^{35}\right.$ S $]$ methionine-labeled cells. Extracts from asynchronous human fibroblasts were lysed and immunoprecipitated either with affinity-purified anti-cyclin D1 (lane 2) or with normal rabbit serum (lane 3). $\left[{ }^{35} \mathrm{~S}\right] \mathrm{Methionine-labeled}$ in vitro translated human cyclin D1 was used as a marker (lane 1). (C) Partial proteolytic map of $\left[{ }^{35}\right.$ S $]$ methionine-labeled cyclin D1. In vitro translated human cyclin D1 (lanes 1,3 ) or immunoprecipitated cyclin D1 from $\left[{ }^{35}\right.$ S methionine-labeled human fibroblasts $($ lanes 2,4) was subjected to partial digestion with V8-protease (lanes 1,$2 ; 10 \mathrm{ng}$; lanes 3,4; $100 \mathrm{ng}$ ). (M) molecular mass markers. The arrowhead indicates cyclin D1. 
Spring Harbor Laboratory). Human lung fibroblasts therefore express relatively large amounts of cyclin D1 but do not express cyclins D2 or D3. In all subsequent experiments we used only human lung fibroblasts (ATCC IMR90).

\section{Cyclin D1 in cells stimulated to grow}

We sought to analyze the accumulation of cyclin D1 in quiescent or growing fibroblasts. Cells were cultured in the absence of serum for 3 days, which resulted in $<1 \%$ of the cells growing, as assessed by both 5-bromodeoxyuridine (BrdU) incorporation during a 24-hr incubation period and by flow cytometry (data not shown; Pepperkok et al. 1988b). Quiescent cells were stimulated with serum and sampled at 4 -hr intervals thereafter. In Figure 2A, the percentage of cells in S-phase after serum stimulation is shown. Cells started to synthesize DNA $12 \mathrm{hr}$ postserum addition, and by $24 \mathrm{hr} \sim 80 \%$ of the cells had entered S-phase. Cell extracts were also made and analyzed by SDS-PAGE and immunoblotting with antibodies to cyclin D1 or cyclin A (Fig. 2B). The level of cyclin D1 was low in quiescent cells; it then increased steadily until $\sim 20 \mathrm{hr}$ postserum addition. At $\sim 24 \mathrm{hr}$, a decrease in cyclin D1 accumulation was observed. This was consistently found in different experiments and may reflect an increased turnover of the protein at the time cells enter S-phase. Given that a fraction $(20-30 \%)$ of the cells had not entered S-phase by $24 \mathrm{hr}$ postserum addition, it cannot be excluded that the residual cyclin D1 detected at $24 \mathrm{hr}$ was derived from $\mathrm{G}_{1}$ cells. Cyclin D1 began to reaccumulate by $32 \mathrm{hr}$, but by that time the cell population had lost synchrony. Cyclin A appeared later, $12 \mathrm{hr}$ postserum addition, and accumulated steadily until $28 \mathrm{hr}$, as described.

The accumulation of cyclin Dl was also analyzed by giving pulses of $\left[{ }^{35} \mathrm{~S}\right]$ methionine to cells while they progressed through the cell cycle and then immunoprecipitating the cyclin from the cell extracts (Fig. 2C). A dramatic increase in cyclin D1 level was observed between 8 and $12 \mathrm{hr}$, with a maximum at $\sim 20 \mathrm{hr}$ after stimulation. The accumulation of the labeled cyclin D1 then decreased by $24 \mathrm{hr}$, as a result of either a decrease in its rate of synthesis or an accelerated degradation.

In conclusion, cyclin Dl levels were reduced in quiescent cells, and in early $G_{1}$ the protein was synthesized rapidly and accumulated steadily. As cells entered S-phase, the protein accumulation appeared to decrease.

\section{Cellular localization of cyclin D1}

We then asked whether the subcellular distribution of cyclin Dl changed in growing cells. We used indirect immunofluorescence to examine the cyclin D1 staining in asynchronous cells, as well as in serum-deprived or serum-stimulated cells \{Fig. 3\}. In asynchronously growing cells, the immunofluorescence signal was located predominantly in the nucleus (Fig. 3A). The specificity of the antibody response was demonstrated by incubation
A

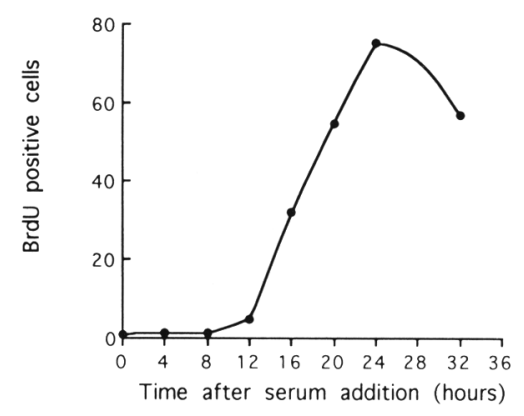

B
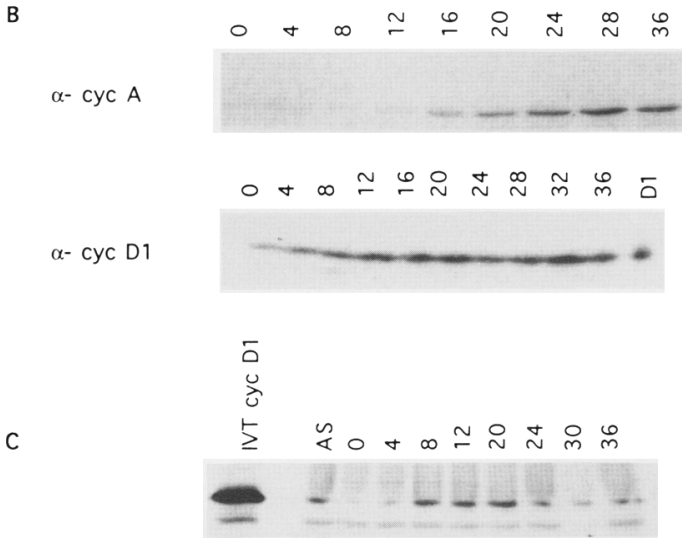

Figure 2. Accumulation of cyclin D1 in human fibroblasts stimulated to grow. (A) DNA synthesis. $\mathrm{G}_{0}$-arrested cells obtained by serum deprivation were stimulated by adding $20 \%$ FCS. BrdU was added simultaneously to monitor DNA synthesis. At the indicated times, cells were fixed and stained for BrdU detection. The graph indicates the percentage of BrdU-positive cells. Each value represents a minimum of 200 cells counted and is the mean of three independent experiments. $|B|$ Cyclin $A$ and cyclin D1 immunoblotting. Extracts (100 $\mu \mathrm{g}$ total protein) were prepared from cells at different times after serum addition and were analyzed by SDS-PAGE $(12.5 \%$ gel $)$ and immunoblotting with affinity-purified anti-cyclin Dl or polyclonal anti-cyclin A. $|C|$ Cyclin D1 synthesis. Cells were pulse labeled with $\left[{ }^{35} \mathrm{~S}\right]$ methionine for $2 \mathrm{hr}$ before harvesting at the indicated times after serum readdition. For each sample, equivalent amounts of TCA-precipitable cpm were immunoprecipitated with affinitypurified anti-cyclin D1 antibodies and analyzed by SDS-PAGE $(12.5 \%$ gel $\left.) .{ }^{35} \mathrm{~S}\right]$ Methionine-labeled in vitro translated human cyclin Dl was used as a marker.

with the antigen before the addition to the coverslip completely abolished the nuclear fluorescence. In contrast, the perinuclear stain was nonspecific and was the result of the anti-rabbit secondary antibody (data not shown). Using different anti-cyclin D1 monoclonal antibodies (J. Lukas, M. Pagano, J. Bartek, and G. Draetta, in prep.), we also found that in asynchronously growing cells the cyclin D1 staining was exclusively nuclear.

In quiescent cells, a very low intensity-specific cytoplasmic staining was detected (Fig. 3B). After serum ad- 

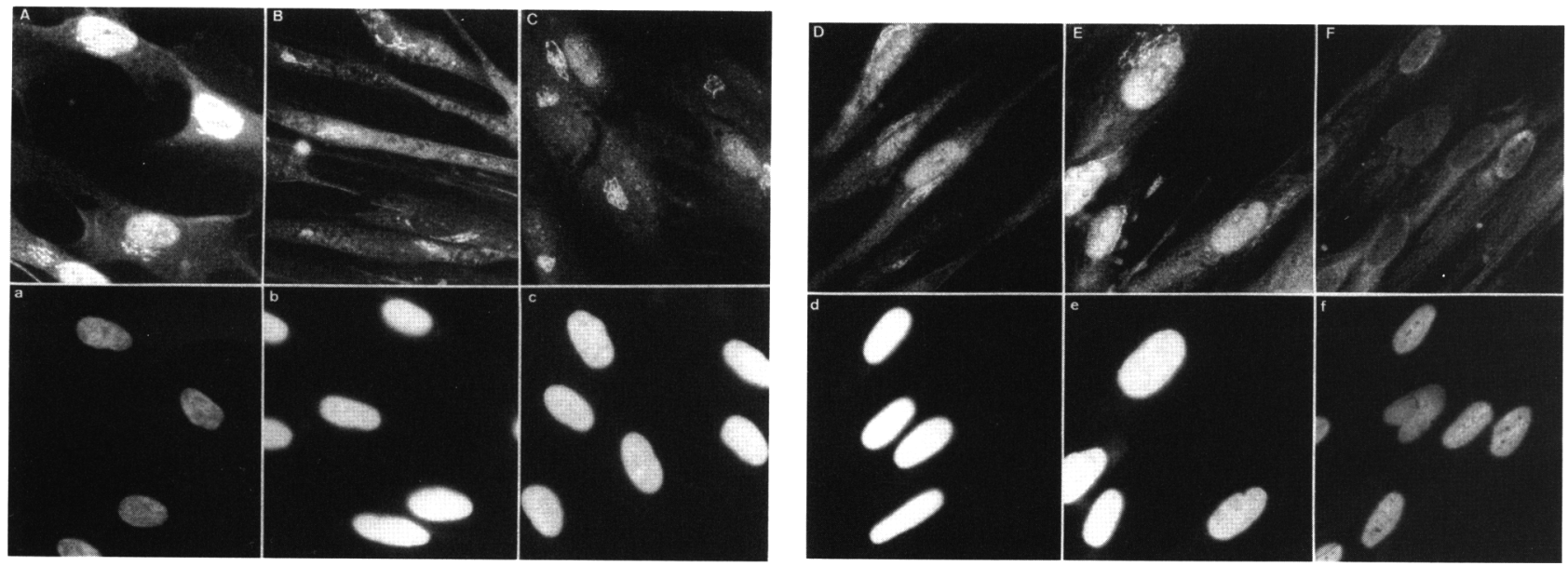

Figure 3. Immunolocalization of cyclin Dl in human fibroblasts. Asynchronous, $\mathrm{G}_{0}$-arrested and -restimulated human fibroblasts were fixed and stained with affinity-purified anti-cyclin D1 antibodies (top) and with Hoechst 33258 (bottom). $(A, a)$ Asynchronous cells; $(B, b) \mathrm{G}_{0}$-arrested cells; $(C, c, D, d, E, e\},\{F, f) 4,8,16$, and 24 hr postserum addition, respectively.

dition, cyclin D1 began to accumulate in the nucleus. The nuclear localization was maintained until 16-18 hr after serum addition (Fig. 3C-E) and then disappeared as cells entered DNA synthesis, at $24 \mathrm{hr}$ postserum addition (Fig. 3F). Similar results were obtained when cells were fixed with paraformaldehyde or with paraformaldehyde-methanol.

The disappearance of cyclin D1 from the nucleus during S-phase was striking. We decided to repeat the experiment by sampling cells at short intervals for $24 \mathrm{hr}$ while testing simultaneously for BrdU incorporation and cyclin D1 staining. The results of two independent experiments are shown in Figure 4A. Cyclin Dl disappeared from the nucleus as cells entered S-phase. BrdU-negative cells showed a clear nuclear accumulation of cyclin D1. Most of the cells that incorporated BrdU had no cyclin D1 in the nucleus; however, $5-10 \%$ of those cells showed a low-intensity cyclin D1 staining. Similar results were obtained when continuously cycling cells, as opposed to cells exiting quiescence, were analyzed (Fig. 4B|. We examined asynchronously growing cells by double anti-cyclin D1-propidium iodide staining and found that the cyclin D1 staining was restricted essentially to cells in $\mathrm{G}_{1}$ (J. Lukas, M. Pagano, J. Bartek, and G. Draetta, in prep.). The exclusion of the protein from the nucleus might play a determining role in the entry into S-phase.
A

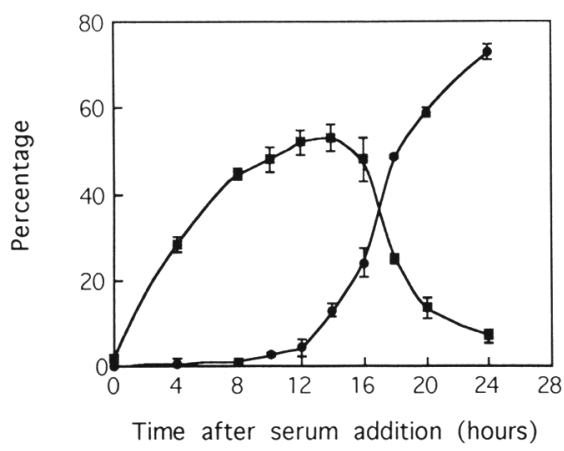

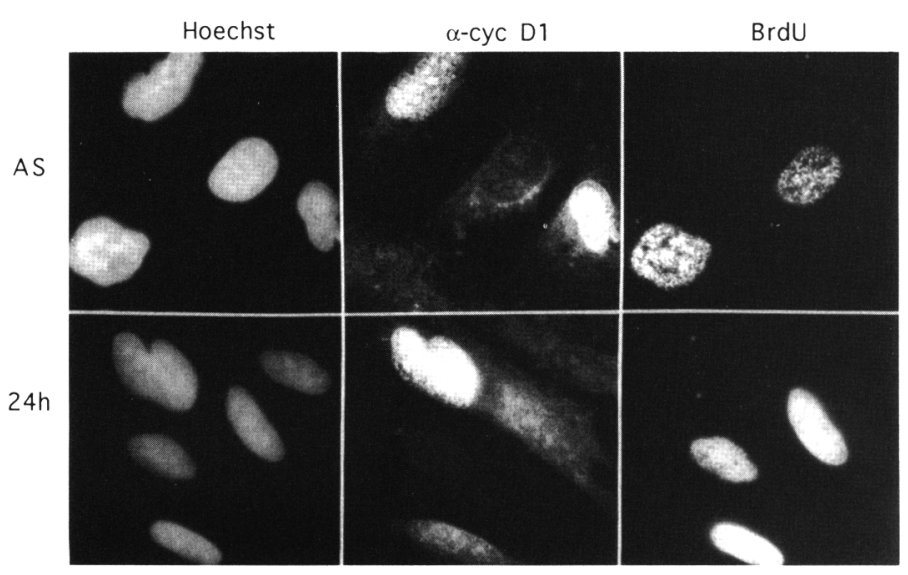

Figure 4. Cyclin D1 disappears from the nucleus as cells synthesize DNA. (A) Nuclear cyclin D1 staining and DNA synthesis. $\mathrm{G}_{0}$-arrested cells were stimulated to enter the cell cycle upon the addition of serum, and BrdU was added simultaneously. Cells were fixed and stained to detect cyclin D1 and BrdU at the indicated times. (a) Cyclin Dl; (O) BrdU. Each value represents a minimum count of 200 cells and is the mean ( \pm S.E.) of three independent experiments. $(B)$ Indirect immunofluorescence of cyclin Dl and BrdU in asynchronous cells (top) and in cells fixed $24 \mathrm{hr}$ after serum addition (bottom). 
Inhibition of cell cycle progression by microinjection of antisense plasmid and antibodies to cyclin D1

To assess the role of cyclin D1 in the early phases of the cell cycle, affinity-purified antibodies to cyclin D1 and a plasmid containing the full-length cyclin D1 cDNA in antisense orientation were microinjected at different times before or after serum addition to quiescent cells. BrdU was added just after microinjection to monitor DNA synthesis. To identify the plasmid-injected cells, normal rabbit antibodies were coinjected. At $24 \mathrm{hr}$ postserum addition, cells were fixed and double stained with an anti-BrdU mouse monoclonal antibody and anti-rabbit antibodies.

In Figure 5, the results of a typical microinjection experiment are shown. Photographs of cells microinjected with cyclin D1 antibodies (Fig. 5A-C) and photographs of antisense plasmid microinjection (Fig. 5D-F) are shown. Cells microinjected with either antibodies or antisense plasmid were prevented from entering DNA synthesis. Microinjection of control antibodies or control vector (Fig. 5, G-I) did not result in any significant inhibition.

To demonstrate that the antisense microinjections were preventing cyclin D1 expression, $16 \mathrm{hr}$ after injection cells were fixed and stained with anti-cyclin D1 antibodies and cyclin Dl was undetectable (Fig. 5K-L).

Three different sets of experiments, in which cells were injected before serum addition or 8 and $16 \mathrm{hr}$ postserum addition, were performed and quantitatively analyzed (Fig. 6A). The results showed unequivocally that cyclin D1 antibody or antisense cyclin D1 plasmid microinjections at 0 or $8 \mathrm{hr}$ postserum addition caused a severe inhibition of DNA synthesis. Microinjections at $16 \mathrm{hr}$ were ineffective, suggesting that some critical cyclin Dl-induced events had been accomplished by that time and demonstrating that DNA synthesis inhibition was specific and not the result of a toxic component present in the microinjected solutions.

The specific inhibitory effect of our affinity-purified anti-cyclin Dl antibodies was also demonstrated by the fact that preadsorption of the antibodies on cyclin D1Sepharose beads, but not on cyclin A or control [bovine serum albumin (BSA)] beads, completely abolished the inhibition of entry into S-phase (Fig 6B).

We compared the inhibitory effects of anti-cyclin A and $\mathrm{Dl}$ antibody microinjections at different times during $\mathrm{G}_{1}$ (Fig. 7). It has been shown previously that antibodies to cyclin $\mathrm{A}$ or $\mathrm{Cdk} 2$ prevent DNA synthesis when injected at any time during $G_{1}$, until just before the start of DNA synthesis (Pagano et al. 1992b, 1993). We found that microinjections in early $G_{1}$ of either cyclin $A$ or cyclin D1 antibodies inhibited entry into S-phase. Microinjections of anti-cyclin D1 antibodies between 14 and $16 \mathrm{hr}$ postserum addition were ineffective. Conversely, anti-cyclin A antibodies were still inhibitory at those times. By $16 \mathrm{hr}, 30 \%$ of the cells had already started DNA synthesis, yet cyclin A antibody microinjection was fully inhibitory. Therefore, it cannot be excluded that cyclin A plays a role in the elongation steps of DNA synthesis, as opposed to being required for initiation. Taken together, these results allow us to conclude that in human fibroblasts, cyclin D1 is required for progression through $G_{1}$ and acts at an earlier point in the cell cycle than cyclin $\mathrm{A}$.

\section{Discussion}

In this paper we have shown that human lung fibroblasts express cyclin D1 as their sole D cyclin. The cyclin D1 level was low in quiescent cells and it increased as cells progressed into $G_{1}$. In S-phase, the accumulation of the protein decreased. By immunofluorescence, the protein was found to be localized in the nucleus and to disappear during S-phase. Microinjection of antisense plasmids or antibodies to cyclin D1 caused cells to arrest prior to S-phase. Time-course experiments showed that cyclin Dl acts at an earlier point in the cell cycle than cyclin A.

Several findings have suggested that cyclin D1 is playing a role in the $G_{1} / S$ transition of the cell cycle. Cyclin Dl was isolated as the product of a gene transcribed late in $G_{1}$, upon stimulation of quiescent cells (Matsushime et al. 1991). It was identified through a yeast screen for $G_{1}$ cyclins on the basis of the complementation of a triple defect in the S. cerevisiae CLNcyclins (Xiong et al. 1991). It was also shown that during $G_{1}$, cyclin $D 1$ is phosphorylated and associated with a Cdc2-related $M_{\mathrm{r}}$ 34,000 protein (Matsushime et al. 1991). The results described in this paper therefore demonstrate that cyclin $\mathrm{Dl}$ is required for cell cycle progression in $\mathrm{G}_{1}$. What could the cyclin D1 targets in $G_{1}$ be? Matsushime et al. (1992) have shown that cyclins D1, D2, and D3 associate with the PSK- $\mathrm{j} 3(\mathrm{Cdk} 4)$ protein kinase in mouse cells. The cyclin D-Cdk4 complexes assembled in vitro phosphorylate $\mathrm{pRb}$ and $\mathrm{p} 107$ in vitro. It has therefore been suggested that in $G_{1}$ the $D 1$ cyclins activate cell cycle progression by phosphorylating negative-growth regulators. Hinds et al. (1992) found that transient transfection of cyclin D1 in cells arrested by overexpression of $\mathrm{pRb}$ partially rescued those cells, without inducing $\mathrm{pRB}$ phosphorylation. These investigators suggest that a physical interaction between $\mathrm{pRb}$ and cyclin $\mathrm{Dl}$ might inhibit the pRb-mediated cell cycle block.

Our experiments also address the issue of the regulation of $G_{1}-c y c l i n$ inactivation. We suggest that the exclusion of cyclin D1 from the nucleus and/or its degradation are required for progression into S-phase. This could explain why it has been difficult to obtain stable clonal cell lines overexpressing D cyclins (C. Sherr, D. Beach, and S. Friend, pers. comm.). We microinjected cyclin D1-encoding plasmids into quiescent cells and found that those cells expressed high levels of cyclin D1 and were unable to reenter the cell cycle upon the addition of serum (V. Baldin and G. Draetta, unpubl.). These effects might be due to the fact that cyclin D1 overexpression exceeds the capacity of a proteolytic system responsible for degrading the protein at the end of $G_{1}$ or of a system responsible for the exclusion of the protein from the nucleus, if any. Matsushime et al. (1992) found that in late $G_{1}$, cyclin D1 is turned over rapidly, with a 

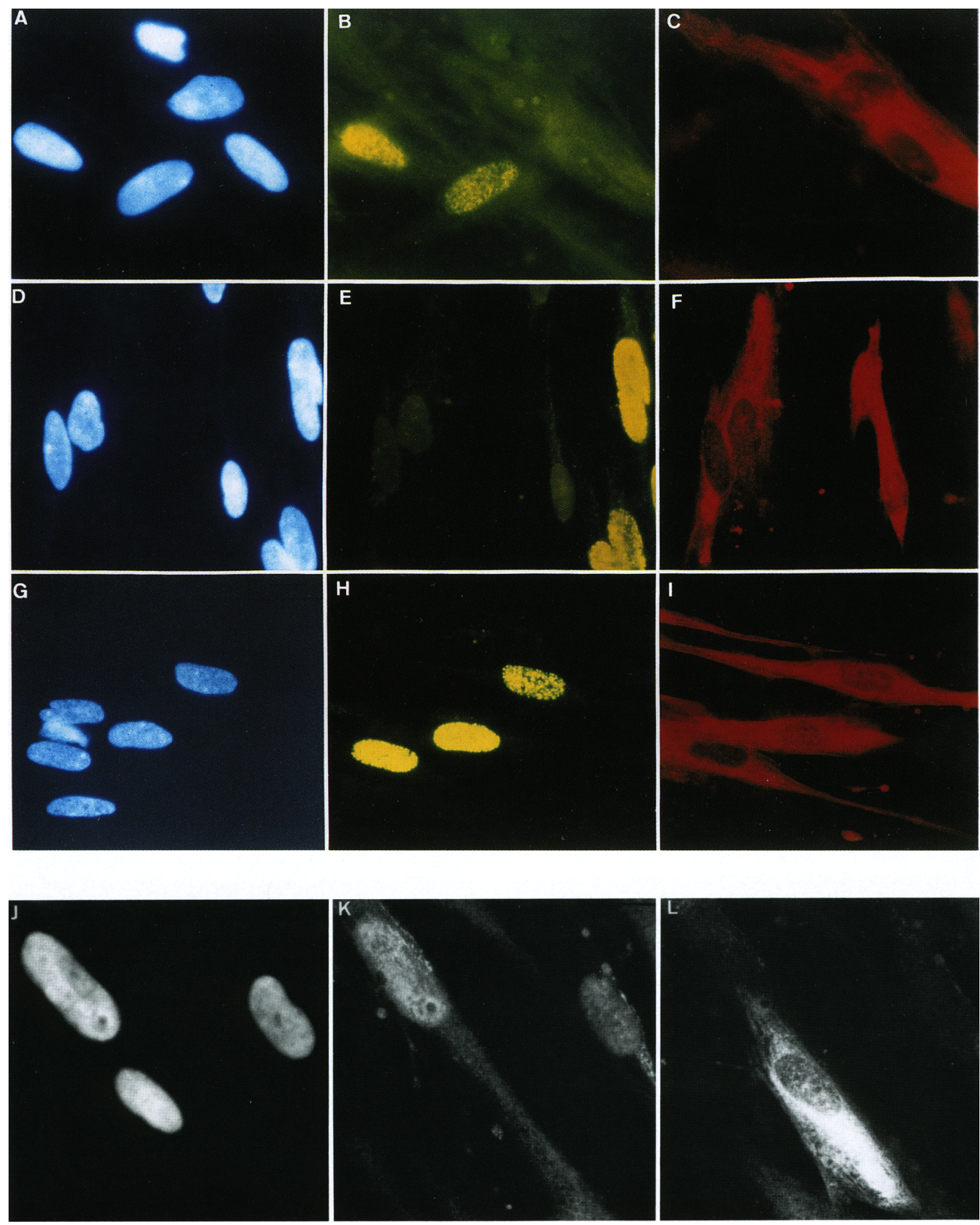

Figure 5. Cyclin D1 antibody and antisense plasmid microinjection in human fibroblasts. Microinjections were performed 8 hr after the addition of serum. BrdU was added at the same time, and cells were incubated for an additional $16 \mathrm{hr}$. Cells were then fixed and stained. $\{A, D, G)$ Hoechst staining; $(B, E, H)$ BrdU detection; $(C, F, I)$ detection of injected cells with Texas red-conjugated goat anti-rabbit antibodies. $(A-C)$ Cells injected with affinity-purified anti-cyclin D1 antibodies; $(D-F)$ cells injected with both antisense cyclin D1 and purified normal rabbit antibodies; $|G-I\rangle$ cells injected with both control plasmid and purified normal rabbit antibodies. $(L-L)$ cells microinjected with antisense D1 plasmid and with control mouse immunoglobulins just before serum addition and fixed/stained 16 hr after. $(J)$ Hoechst staining; $(K)$ cyclin Dl detection; $(L)$ detection of injected cells by staining with FITC-conjugated anti-mouse antibodies. 
A

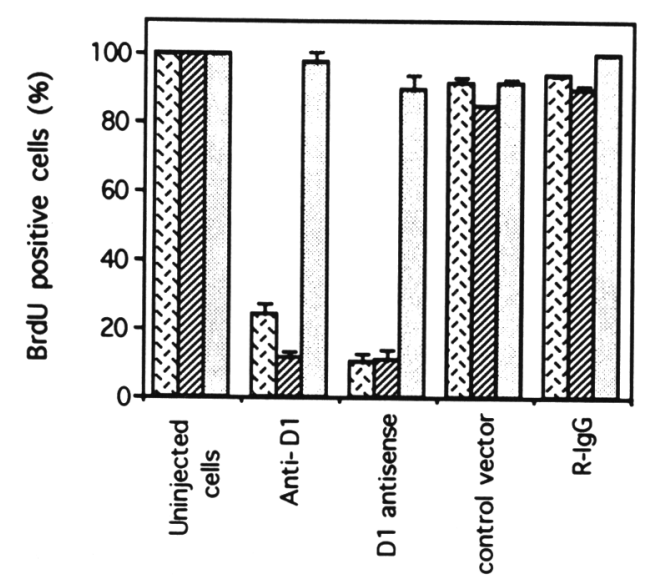

B

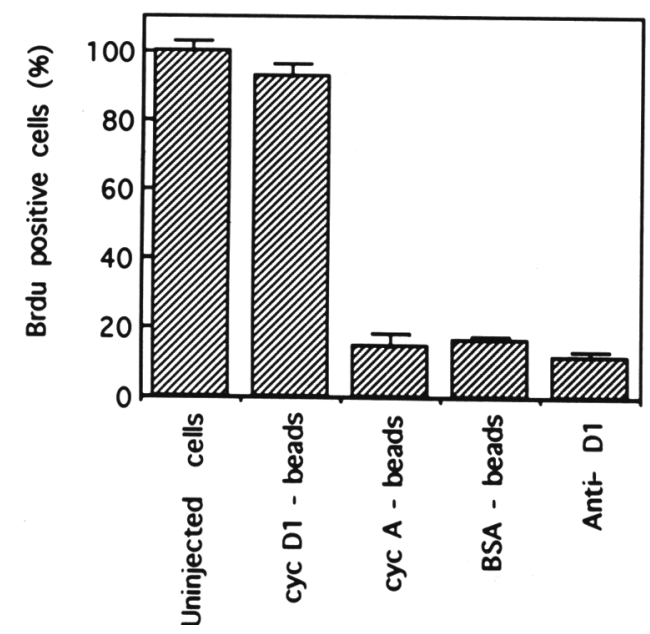

Figure 6. Time course of microinjection. (A) Cells 100-120 were injected per each experimental point. BrdU was added at the time of injection. The three columns represent injections at 0 (strippled bar), 8 (hatched bar), and $16 \mathrm{hr}$ (shaded bar) postserum addition, respectively. BrdU-positive cells $\langle \%|$ were calculated as the ratio of injected BrdU-positive cells to BrdU-positive surrounding cells $\times 100$. The results are the mean $( \pm$ S.E. $)$ of three independent experiments. $(B)$ Specificity of cyclin D1 antibodies. Affinity-purified anti-cyclin D1 antibodies $(2 \mathrm{mg} / \mathrm{ml})$ were incubated for $2 \mathrm{hr}$ with either cyclin D1-Sepharose, cyclin A-Sepharose, or BSA-Sepharose. This was repeated twice, and the final supernatant was used for microinjection. Cells were fixed and stained $24 \mathrm{hr}$ postserum addition. The results are the mean ( \pm S.E.) of two independent experiments.

half-life of $\leqslant 20 \mathrm{~min}$. In preliminary experiments, we found that when cells were arrested in S-phase using DNA synthesis inhibitors, the level of cyclin D1 was reduced severely (V. Baldin and J. Lukas, unpubl.). Recent experiments have shown that in human fibroblasts, cyclin D1 interacts with PCNA, one of the factors required for the initiation of DNA replication (Xiong and Beach 1992). The interaction with cyclin D1 might prevent PCNA from binding to the initiation complex. Al- together these findings suggest that the nuclear exclusion of cyclin Dl or its degradation, or both, are required for progression through S-phase.

How then could we explain the overexpression of cyclin D1 in many tumors? In all overexpressing cell lines tested there was no evidence that the cyclin D1 mRNAs contained mutations in the protein-coding region (G. Peters, pers. comm.). We propose that overexpression of cyclin D1 driven by an heterologous promoter region relieves the tumor cell from an upstream control and therefore gives a growth advantage to the cell. However, cyclin D1 overexpression needs to be finely balanced to avoid saturating the degradation machinery. The increased levels of cyclin D1 in different tumor cell lines, with one or two exceptions, never dramatically exceeds the levels detected in normal fibroblasts, even in those cell lines that show large increases in the cyclin D1 mRNA (J. Lukas, M. Pagano, J. Bartek, and G. Draetta, in prep.; Lammie et al. 1991).

Our data suggest that cyclin D1 is regulated in a cell cycle-dependent manner. By sequence comparison with other known cyclins, it is clear that D cyclins lack the amino-terminal domain shown to be essential for ubiquitin-mediated degradation (Glotzer et al. 1990). Further studies should be attempted to determine the nature of the signals that trigger cyclin D1 degradation and its disappearance from the nucleus, as well as the dependence of these effects on the interaction of cyclin Dl with members of the Cdk family.

\section{Materials and methods \\ Cell culture and synchronization}

Human diploid lung fibroblasts (IMR-90), obtained from the American Type Culture Collection, were cultured for no longer than seven passages in Dulbecco's modified Eagle medium (DMEM) supplemented with $10 \%$ heat-inactivated fetal calf serum (FCS), 2 mM glutamine, penícillin (100 U/ml), and strepto-

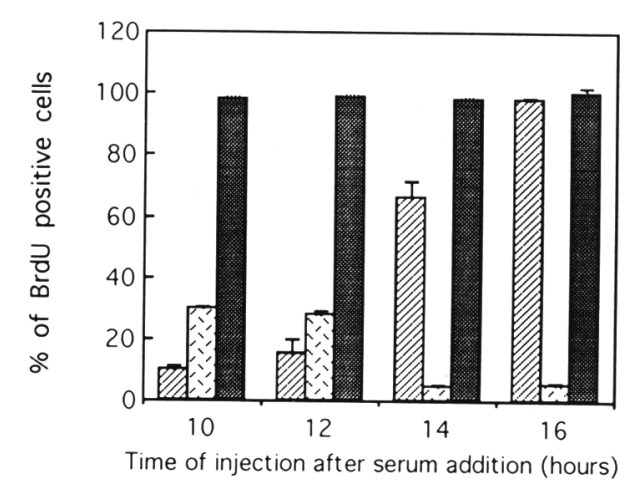

Figure 7. Anti-cyclin A and anti-cyclin Dl antibody microinjections. Cells were injected with affinity-purified, anti-cyclin D1 (hatched bar), affinity-purified anti-cyclin A (strippled bar), or purified normal rabbit antibodies (shaded bar) at the times indicated after serum addition. BrdU was added at the time of injection. Values were calculated as in Fig. $6 \mathrm{~A}$ and are the mean $( \pm S . E$.$) of three independent experiments.$ 
mycin $(100 \mu \mathrm{g} / \mathrm{ml})$, in a humidified atmosphere containing $5 \%$ $\mathrm{CO}_{2}$ at $37^{\circ} \mathrm{C}$. Cells were arrested in $\mathrm{G}_{0}$ by incubating them for 3 days in DMEM without serum. They were stimulated to reenter the cell cycle by adding $20 \%$ FCS. Cell cycle progression was monitored by measuring BrdU incorporation /see Immunofluorescence, below). For $\left[{ }^{35} \mathrm{~S}\right]$ methionine labeling, cells were preincubated for $30 \mathrm{~min}$ in methionine-free DMEM (GIBCO) supplemented with dialyzed FCS (GIBCO), followed by the addition of $\left[{ }^{35} \mathrm{~S}\right]$ methionine $(1000 \mathrm{Ci} / \mathrm{mmole}$; Amersham) to a final concentration of $250 \mu \mathrm{Ci} / \mathrm{ml}$ for $2 \mathrm{hr}$.

\section{Construction of sense and antisense cyclin D1 plasmids}

The full-length cDNA coding for human cyclin Dl was subcloned from the pGEX-D11 vector (kindly provided by D. Beach, Cold Spring Harbor Laboratory! in which a 1-kb human cyclin D1 cDNA (Xiong et al. 1991) had been cloned into Ncol-HindIII sites of pGEX-KG (Guan and Dixon 1990). To obtain sense cyclin D1 plasmid, the cDNA was excised from the parental plasmid by a double digestion with EcoRI and HindIII and subcloned in a DNA expression vector, driven by the cytomegalovirus (CMV) promoter (pX vector; Superti-Furga et al. 1991), digested with the same enzymes. Antisense cyclin D1 plasmid was obtained by subcloning the cyclin $\mathrm{Dl}$ insert in a $\mathrm{pXnv}$ vector (modified pX vector; V. Baldin and G. Draetta, unpubl.|) digested with HindIII-EcoRI. These constructs were transformed into Escherichia coli DH5 $\alpha$. For microinjections, plasmids were purified by cesium chloride centrifugation.

\section{Antibody production and purification}

Human cyclin D1 protein was produced from the bacterial strain BL21(DE3) using a pET-cyclin D1 expression vector (a gift of D. Beach). After isopropyl $\beta$-D-thiogalactoside (IPTG) induction for $4 \mathrm{hr}$, (1 $\mathrm{mm}$ final concentration), cyclin Dl was extracted from the insoluble inclusion bodies with $8 \mathrm{M}$ urea and successively dialyzed into $4 \mathrm{M}, 2 \mathrm{M}, 1 \mathrm{M}$ urea and, finally, into buffer A [100 mM Tris- $\mathrm{HCl}$ (pH 8), $1 \mathrm{~mm} \mathrm{DTT,} 5 \mathrm{mM} \mathrm{MgCl}_{2}$, 1 mM EDTA, $200 \mathrm{~mm} \mathrm{NaCl}$. Cyclin Dl was then purified on a Mono-Q column (Pharmacia), eluted at $400-500 \mathrm{~mm} \mathrm{NaCl}$, and dialyzed into phosphate-buffered saline (PBS). Rabbits were injected with $0.5 \mathrm{mg}$ of purified cyclin Dl in complete Freund's adjuvant. Subsequently, they were injected with the same amount of protein in incomplete Freund's adjuvant every 2 weeks until a significant immune signal was detected by immunoblot on total cell extracts. The resulting polyclonal antiserum was affinity purified using purified cyclin D1 covalently coupled to $\mathrm{CNBr}$-activated Sepharose $4 \mathrm{~B} ; 5 \mathrm{ml}$ of immune serum was incubated batch-wise with $3 \mathrm{ml}$ of cyclin Dl-Sepharose pre-equilibrated with $50 \mathrm{~mm}$ Tris- $\mathrm{HCl}(\mathrm{pH} 7.4), 150 \mathrm{~mm}$ $\mathrm{NaCl}$, and $0.1 \%$ Triton X-100. After overnight incubation at $4^{\circ} \mathrm{C}$, the Sepharose beads were poured into a column and washed with equilibration buffer. Ten milliliters of glycine- $\mathrm{HCl}$ at $\mathrm{pH}$ $2.3(0.1 \mathrm{M})$, in $500 \mu \mathrm{l}$ aliquots, was applied to elute the antibodies. Fractions were neutralized with $50 \mu \mathrm{l}$ of $1 \mathrm{M}$ Tris $-\mathrm{HCl} / \mathrm{pH}$ 9.5). Fractions containing pure immunoglobulins were mixed, and the protein concentration was determined. The preparation and characterization of the anti-cyclin $\mathrm{A}$ antibodies have been described previously (Pagano et al. 1992b). For microinjection experiments, the antibodies were concentrated by centrifugation using Centricon 10 tubes (Amicon).

\section{Immunoblotting and immunoprecipitation}

Whole-cell lysates were obtained by lysing cells, $30 \mathrm{~min}$ at $4^{\circ} \mathrm{C}$, in the following buffer: $50 \mathrm{mM}$ Tris- $\mathrm{HCl}$ (pH 7.5), $250 \mathrm{mM} \mathrm{NaCl}$,
$0.1 \%$ Triton X-100, 5 mM EDTA, $50 \mathrm{~mm} \mathrm{NaF}, 0.1 \mathrm{~mm}$ sodium orthovanadate, $0.1 \mathrm{~mm}$ phenylmethylsulfonyl fluoride, $1 \mu \mathrm{g} / \mathrm{ml}$ of leupeptin, $10 \mu \mathrm{g} / \mathrm{ml}$ of soybean trypsin inhibitor, $10 \mu \mathrm{g} / \mathrm{ml}$ of tosyl phenylalanine chloromethyl ketone, $10 \mu \mathrm{g} / \mathrm{ml}$ of tosyl amido phenyl butanol, and $1 \mu \mathrm{g} / \mathrm{ml}$ of aprotinin. For immunoblotting, $100 \mu \mathrm{g}$ of total protein was loaded per lane. Proteins were analyzed by gel electrophoresis on SDS- $12.5 \%$ polyacrylamide gels and transferred to nitrocellulose by semidry blotting, as described by Harlow and Lane (1988). Filters were probed using affinity-purified antibodies as described in Pagano et al. (1992a). Immunoprecipitations were performed as described by Schindler et al. (1992).

\section{Partial proteolytic mapping of cyclin D1}

$\left[{ }^{35} \mathrm{~S}\right]$ Methionine cell extracts $(2 \mathrm{mg})$ or in vitro-translated human cyclin D1 [made in rabbit reticulocyte lysate according to Ducommun et al. [1991)| were immunoprecipitated with anticyclin D1 antibodies and subjected to SDS-PAGE electrophoresis. The $35-\mathrm{kD}$ bands corresponding to cyclin D1 were located by autoradiography, excised, and subjected to limited proteolysis with Staphylococcus aureus V8-protease as described by Cleveland et al. (1977). In brief, bands were placed in the sample wells of a $15 \%$ SDS gel and overlayed with V8-protease 10 or $100 \mathrm{ng}$. Digestion proceeded in the stacking gel during electrophoresis.

\section{Immunofluorescence}

Cells growing on glass coverslips were washed once with PBS, fixed for $5 \mathrm{~min}$ at room temperature with $100 \%$ cold methanol, and permeabilized with $0.25 \%$ Triton X-100 in PBS for 5 min at room temperature. Fixed and permeabilized cells were incubated for $1 \mathrm{hr}$ at $37^{\circ} \mathrm{C}$ in a humidified atmosphere with affinitypurified polyclonal or monoclonal anti-cyclin D1 antibodies (dilution $1: 250$ and $1: 50$, respectively|. They were then washed three times with $0.5 \%$ BSA in PBS and incubated for $30 \mathrm{~min}$ with Texas red-conjugated goat anti-rabbit antibodies (dilution $1: 200$, Amersham, UK) or anti-mouse biotinylated antibodies (dilution 1: 100; Vector Laboratories). For cyclin D1 detection with the monoclonal antibody, a third incubation with fluorescein-conjugated streptavidin /dilution $1: 100$; Vector Laboratories) was done. Coverslips were washed once with $0.5 \%$ BSA in PBS, twice with PBS, and finally incubated for $5 \mathrm{~min}$ at room temperature with a $1-\mu \mathrm{g} / \mathrm{ml}$ solution of Hoechst dye 33258 (Sigma) in PBS. After three additional washes with PBS, coverslips were mounted on glass slides with Mowiol, and examined on a Zeiss Axiophot microscope using a Neofluar $63 \times$ lens. Photographs were taken on Fuji P1600 film. For BrdU staining, cells were fixed, permeabilized, and incubated with the appropriate antibody as described above. They were then washed with PBS and incubated for $10 \mathrm{~min}$ at room temperature in $1.5 \mathrm{M} \mathrm{HCl}$. After three washes with PBS cells were incubated for $30 \mathrm{~min}$ with monoclonal anti-BrdU (dilution 1:100; Partec). After three washes with $0.5 \%$ BSA in PBS, cells were incubated for 30 min with fluorescein-conjugated anti-mouse antibodies (dilution 1 : 100, Sigmal, washed, and mounted with Mowiol.

\section{Microinjection experiments}

Affinity-purified antibodies (anti-cyclin D1 or anti-cyclin $\mathrm{A}_{i} 2$ $\mathrm{mg} / \mathrm{ml})$, a plasmid carrying full-length cyclin Dl antisense cDNA $(100 \mathrm{ng} / \mathrm{ml})$, and a control vector (without any cDNA; $100 \mathrm{ng} / \mathrm{ml}$ ) or control marker (purified rabbit antibodies; $2 \mathrm{mg}$ / $\mathrm{ml}$ ) were microinjected into the cytoplasm or the nucleus of cells using an Eppendorf micromanipulator and microinjector 
(AIS, Zeiss) (Ansorge and Pepperkok 1988; Pepperkok et al. 1988b, 1990). Using this system the percentage of successfully microinjected cells was $>90 \%$ for cytoplasmic and $85 \%$ for nuclear microinjections (Pepperkok et al. 1988a). Immediately after injection the growth medium was supplemented with BrdU (Sigma) at the final concentration of $100 \mu \mathrm{M}$. Cells were fixed 24 $\mathrm{hr}$ after serum addition. Immunofluorescence processing with anti-BrdU or anti-rabbit antibodies was performed as described above.

\section{Acknowledgments}

We are grateful to Rainer Pepperkok for advice on microinjection. We thank David Beach for cyclin D plasmids, Graham Smith for helping with flow cytometry, Monika Stein for technical assistance, and Leonardo Brizuela, Sara Courtneidge, Eric Karsenti, and Enzo Sorrentino for critically reading the manuscript. G.D. was supported in part by NATO grant CGR900652. V.B. was supported by a postdoctoral fellowship from Association pour la Recherche sur le Cancer (France), J.L. was supported by a fellowship from EMBO, and M.J.M. was supported by a fellowship from the Ministerio de Educación y Ciencia (Spain).

The publication costs of this article were defrayed in part by payment of page charges. This article must therefore be hereby marked "advertisement" in accordance with 18 USC section 1734 solely to indicate this fact.

\section{References}

Ansorge, W. and R. Pepperkok. 1988. Performance of an automated system for capillary microinjection into living cells. $J$. Biochem. Biophys. Methods 16: 283-292.

Booher, R.N., C.E. Alfa, J.S. Hyams, and D.H. Beach. 1989. The fission yeast $\mathrm{cdc} 2 / \mathrm{cdc13} / \mathrm{sucl}$ protein kinase: Regulation of catalytic activity and nuclear localization. Cell 58: 485-497.

Cleveland, D., S. Fischer, M. Kirschner, and U. Laemmli. 1977. Peptide mapping by limitated proteolysis in sodium dodecyl sulfate and analysis by gel electrophoresis. $J$. Biol. Chem. 252: 1102-1106.

Draetta, G. 1991. Biochemical regulation of the cdc2 protein kinase. In Cellular regulation by protein phosphorylation (ed. L.M.G. Heilmeyer), vol. 56, pp. 363-374. Springer-Verlag, Berlin/Heidelberg, Germany.

Draetta, G., F. Luca, J. Westendorf, L. Brizuela, J. Ruderman, and D. Beach. 1989. cdc2 protein kinase is complexed with both cyclin A and B: Evidence for proteolytic inactivation of MPF. Cell 56: 829-838.

Ducommun, B., P. Brambilla, M.A. Felix, B.J. Franza, E. Karsenti, and G. Draetta. 1991. cdc2 phosphorylation is required for its interaction with cyclin. $E M B O /$. 10: 33113319.

Dulic, V., E. Lees, and S.I. Reed. 1992. Association of human cyclin $\mathrm{E}$ with a periodic G1-S phase protein kinase. Science 257: 1958-1961.

Elledge, S.J. and M.R. Spottswood. 1991. A new human protein kinase, cdk2, identified by complementation of a cdc28 mutation in Saccharomyces cerevisiae, is a homolog of Xenopus Eg1. EMBO I. 10: 2653-2659.

Evans, T., E.T. Rosenthal, J. Youngblom, D. Distel, and T. Hunt. 1983. Cyclin: A protein specified by maternal mRNA in sea urchin eggs that is destroyed at each cleavage division. Cell 33: 389-396.

Forsburg, S.L. and P. Nurse. 1991. Cell cycle regulation in the yeasts Saccharomyces cerevisiae and Schizosaccharomyces pombe. Annu. Rev. Cell Biol. 7: 227-256.
Gautier, J., J. Minshull, M. Lohka, T. Hunt, and J.L. Maller. 1990. Cyclin is a component of MPF from Xenopus. Cell 60: $487-494$.

Ghiara, J.B., H.E. Richardson, K. Sugimoto, M. Henze, D.J. Lew, C. Wittenberg, and S.I. Reed. 1991. A cyclin B homolog in S. cerevisiae: Chronic activation of the cdc 28 protein kinase by cyclin prevents exit from mitosis. Cell 65: 163-174.

Girard, F., U. Strausfeld, A. Fernandez, and N. Lamb. 1991. Cyclin $A$ is required for the onset of DNA replication in mammalian fibroblasts. Cell 67: 1169-1179.

Glotzer, M., A. Murray, and M. Kirschner. 1990. Cyclin is degraded by the ubiquitin pathway. Nature 349: 132-138.

Guan, K. and J.E. Dixon. 1990. Protein tyrosine phosphatase activity of an essential virulence determinant in Yersinia. Science 249: 553-556.

Hadwiger, J.A., C. Wittenberg, M.D. Mendenhall, and S.I. Reed. 1989. The Saccharomyces cerevisiae CKSl gene, a homolog of the Schizosaccharomyces pombe sucl ${ }^{+}$gene, encodes a subunit of the Cdc28 protein kinase complex. Mol. Cell. Biol. 9: 2034-41.

Hamaguchi, J., R. Tobey, J. Pines, H. Crissman, T. Hunter, and E. Bradbury. 1992. Requirement for p34cdc2 kinase is restricted to mitosis in the mammalian cdc2 mutant FT210. J. Cell Biol. 117: 1041-1053.

Hanks, S.K. 1987. Homology probing: Identification of cDNA clones encoding members of the protein-serine kinase family. Proc. Natl. Acad Sci. 84: 388-392.

Harlow, E. and D. Lane. 1988. Antibodies. A laboratory manual. Cold Spring Harbor Laboratory, Cold Spring Harbor, New York.

Hinds, P., S. Mittnacht, V. Dulic, A. Arnold, S. Reed, and R. Weinberg. 1992. Regulation of retinoblastoma protein functions by ectopic expression of human cyclins. Cell 70: 993 1006.

Inaba, T., H. Matsushime, M. Valentine, M. Roussel, C.J. Sherr, and T. Look. 1992. Genomic organization, chromosomal localization, and independent expression of human cyclin D genes. Genomics 13: 565-574.

Jiang, W., S. Kahan, N. Tomita, Y. Zhang, S. Lu, and B. Weinstein. 1992. Amplification and expression of the human cyclin D gene in esophageal cancer. Cancer Res. 52: 29802983.

Kiyokawa, H., X. Busquets, T. Powell, L. Ngo, R.A. Rifkind, and P.A. Marks. 1992. Cloning of a D-type cyclin from murine erythroleukemia cells. Proc. Natl. Acad. Sci. 89: 2444-2447.

Koff, A., F. Cross, A. Fisher, J. Schumacher, K. Leguellec, M. Philippe, and J.M. Roberts. 1991. Human cyclin E, a new cyclin that interacts with two members of the CDC2 gene family. Cell 66: 1217-1228.

Koff, A., A. Giordano, D. Desai, K. Yamashita, W. Harper, S. Elledge, T. Nishimoto, D. Morgan, R. Franza, and J. Roberts. 1992. Formation and activation of a cyclin E-cdk2 complex during the G1 phase of the human cell cycle. Science 257: 1689-1693.

Labbé, J.C., J.P. Capony, D. Caput, J.C. Cavadore, J. Derancourt, M. Kaghdad, J. M. Lelias, A. Picard, and M. Dorée. 1989. MPF from starfish oocytes at first meiotic metaphase is a heterodimer containing one molecule of $\mathrm{cdc} 2$ and one molecule of cyclin B. EMBO J. 8: 3053-3058.

Lammie, G., V. Fantl, R. Smith, E. Schuuring, S. Brookes, R. Michalides, C. Dickson, A. Arnold, and G. Peters. 1991. D11S287, a putative oncogene on chromosome 11q13, is amplified and expressed in squamous cell and mammary carcinomas and linked to BCL-1. Oncogene 6: 439-444.

Lees, E., B. Faha, V. Dulic, S. Reed, and E. Harlow. 1992. Cyclin $\mathrm{E} / \mathrm{cdk} 2$ and cyclin $\mathrm{A} / \mathrm{cdk} 2$ linase associate with p107 and 
E2F in a temporally distinct manner. Genes \& Dev, 5: 1874 1885.

Lew, D.J., V. Dulic, and S.I. Reed. 1991. Isolation of three novel human cyclins by rescue of $\mathrm{G} 1 \mathrm{cyclin}(\mathrm{cln})$ function in yeast. Cell 66: 1197-1206.

Matsushime, H., M. Roussel, R. Ashmun, and C.J. Sherr. 1991. Colony-stimulating Factor 1 regulates novel cyclins during the G1 phase of the cell cycle. Cell 65: 701-713.

Matsushime, H., M. Ewen, D. Strom, J.Y. Kato, S. Hanks, M. Roussel, and C.J. Sherr. 1992. Identification and properties of an atypical catalytic subunit p34PSK-J3 for mammalian D-type G1 cyclins. Cell 71: 323-334.

Meijer, L., D. Arion, R. Golsteyn, I. Pines, L. Brizuela, T. Hunt, and D. Beach. 1989. Cyclin is a component of the sea urchin egg M-phase specific histone $\mathrm{H} 1$ kinase. EMBO J. 8: 22752282.

Meyerson, M., G.H. Enders, C.-L. Wu, L.-K. Su, C. Gorka, C. Nelson, E. Harlow, and L.-H. Tsai. 1992. A family of human cdc2-related protein kinases. EMBO I. 11: 2909-2917.

Minshull, J., J.J. Blow, and T. Hunt. 1989. Translation of cyclin mRNA is necessary for extracts of activated Xenopus eggs to enter mitosis. Cell 56: 947-956.

Minshull, J., R. Golsteyn, C. Hill, and T. Hunt. 1990. The A- and B-type cyclin associated cdc2 kinases in Xenopus turn on and off at different times in the cell cycle. EMBO J. 9: 28652875.

Motokura, T., T. Bloom, Y.G. Kim, H. Jueppner, J. Ruderman, H. Kronenberg, and A. Arnold. 1991. A novel cyclin encoded by a bcll-linked candidate oncogene. Nature 350: 512-515.

Murray, A.W. and M.W. Kirschner. 1989. Cyclin synthesis drives the early embryonic cell cycle. Nature 339: 275-280.

Nigg, E. 1991. The substrates of the cdc2 protein kinase. In Cell cycle control in eukaryotes (ed. G. Draetta), vol 2, pp. 261270. Saunders, Philadelphia, PA.

Ninomiya-Tsuji, J., S. Nomoto, H. Yasuda, S.I. Reed, and K. Matsumoto. 1991. Cloning of a human cDNA encoding a cdc2-related kinase by complementation of budding yeast cdc28 mutation. Proc. Natl. Acad. Sci. 88: 9006-9010.

Okuda, T., J. Cleveland, and J. Downing. 1992. PCTAIRE-1 and PCTAIRE-3, two members of a novel cdc2/CDC28-related protein kinase gene family. Oncogene 7: 2249-2258.

Pagano, M., M. Durst, S. Joswig, G. Draetta, and P. Jansen-Durr. 1992a. Binding of the human E2F transcription factor to the retinoblastoma protein but not cyclin A is abolished in HPV 16-immortalized cells. Oncogene 7: 1681-1686.

Pagano, M., R. Pepperkok, F. Verde, W. Ansorge, and G. Draetta. $1992 \mathrm{~b}$. Cyclin A is required at two points in the human cell cycle. $E M B O$ J. 11: 761-771.

Pagano, M., R. Pepperkok, J. Lukas, V. Baldin, W. Ansorge, J. Bartek, and G. Draetta. 1993. Regulation of the human cell cycle by the cdk2 protein kinase. I. Cell Biol. 121: 101-111.

Pardee, A.B. 1989. Gl events and regulation of cell proliferation. Science 246: 603-614.

Paris, J., R. LeGuellic, A. Couturier, K. LeGuellic, F. Omilli, J. Camonis, S. MacNeill, and M. Philippe. 1991. Cloning by differential screening and characterization of a Xenopus cDNA coding for a protein highly homologous to cdc2. Proc. Natl. Acad. Sci. 88: 1039-1043.

Pepperkok, R., C. Schneider, L. Philipson, and W. Ansorge. 1988a. Single cell assay with an automated capillary microinjection system. Exp. Cell Res. 178: 369-376.

Pepperkok, R., M. Zanetti, R. King, D. Delia, W. Ansorge, L. Philipson, and C. Schneider. 1988b. Automatic microinjection system facilitates detection of growth inhibitory mRNA. Proc. Natl. Acad. Sci. 85: 6748-6752.

Pepperkok, R., M. Helene Bre, J. Davoust, and T.E. Kreis. 1990.
Microtubules are stabilized in confluent epithelial cells but not in fibroblast. I. Cell Biol. 111: 3003-3012.

Pines, J. and T. Hunter. 1989. Isolation of a human cyclin cDNA: Evidence for cyclin mRNA and protein regulation in the cell cycle and for interaction with p34cdc2. Cell 58: 833846 .

- 1991. Cyclin-dependent kinases: A new cell cycle motif? Trends Cell Biol. 1: 117-121.

Riabowol, K., G. Draetta, L. Brizuela, D. Vandre, and D. Beach. 1989. The cdc2 kinase is a nuclear protein that is essential for mitosis in mammalian cells. Cell 57: 393-401.

Rosenberg, C., H. Kim, T. Shows, H. Kronenberg, and A. Arnold. 1991. Rearrangement and overexpression of D11S287E, a candidate oncogene on chromosome $11 \mathrm{q} 13$ in benign parathyroid tumors. Oncogene 6: 449-453.

Schindler, C., K. Shuai, V.R. Prezioso, and J.E. Darnell. 1992. Interferon-dependent tyrosine phosphorylation of a latent cytoplasmic transcription factor. Science 257: 809-813.

Superti-Furga, G., G. Berges, D. Picard, and M. Busslinger. 1991. Hormone-dependent transcriptional regulation and cellular transformation by Fos-steroid receptor fusion proteins. Proc. Natl. Acad. Sci. 88: 5114-5118.

Surana, U., H. Robitsch, C. Price, T. Schuster, I. Fitch, A.B. Futcher, and K. Nasmyth. 1991. The role of CDC28 and cyclins during mitosis in the budding yeast $\mathrm{S}$. cerevisiae. Cell 65: 145-161.

Swenson, K., K.M. Farrell, and J.V. Ruderman. 1986. The clam embryo protein cyclin $A$ induces entry into $M$-phase and the resumption of meiosis in Xenopus oocytes. Cell 47: 861870.

Th'ng. J.P.H., P. Wright, J. Hamaguchi, C.J. Norbury, P. Nurse, and E. Bradbury. 1990. The FT210 cell line is a mouse G2 phase mutant with a temperature-sensitive cdc2 gene product. Cell 63: 313-324.

Tsai, L.-H., E. Harlow, and M. Meyerson. 1991. Isolation of the human cdk2 gene that encodes the cyclin A- and adenovirus E1A-associated p33 kinase. Nature 353: 174-177.

Wang, J., X. Chenivesse, B. Henglein, and C. Brechot. 1990. Hepatitis B virus integration in a cyclin A gene in a hepatocellular carcinoma. Nature 343: 555-557.

Withers, D., R. Harvey, J. Faust, O. Melnyk, K. Carey, and T. Meeker. 1991. Characterization of a candidate bcl-1 gene. Mol. Cell Biol. 11: 4846-4853.

Wittenberg, C., K. Sugimoto, and S. I. Reed. 1990. G1-specific cyclins of S. cerevisiae: Cell cycle periodicity, regulation by mating pheromone, and association with the $\mathrm{p} 34^{c d c 2 s}$ protein kinase. Cell 62: 225-237.

Won, K., Y. Xiong, D. Beach, and M. Gilman. 1992. Growthregulated expression of D-type cyclin genes in human diploid fibroblast. Proc. Natl. Acad. Sci. 89: 9910-9914.

Xiong, Y., T. Connolly, B. Futcher, and D. Beach. 1991. Human D-type cyclin. Cell 65: 691-699.

Xiong, Y., J. Menninger, D. Beach, and D. Ward. 1992. Molecular cloning and chromosomal mapping of CCND genes encoding human D-type cyclins. Genomics 13: 575-584.

Xiong, Y., H. Zhang, and D. Beach. 1992. D type cyclins associate with multiple protein kinases and the DNA replication and repair factor PCNA. Cell 71: 505-514.

Zindy, F., E. Lamas, X. Chenivesse, J. Sobczak, J. Wang, D. Fesquet, B. Henglein, and C. Brechot. 1992. Cyclin A is required in $\mathrm{S}$ phase in normal epithelial cells. Biochem. Biophys. Res. Commun. 182: 1144-1154. 


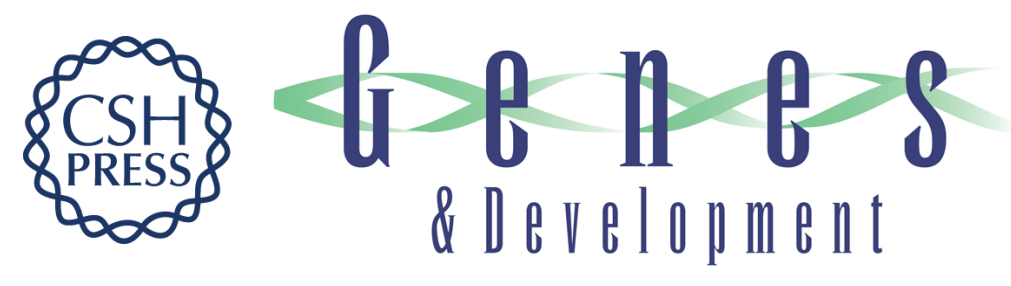

\section{Cyclin D1 is a nuclear protein required for cell cycle progression in G1.}

V Baldin, J Lukas, M J Marcote, et al.

Genes Dev. 1993, 7:

Access the most recent version at doi:10.1101/gad.7.5.812

References This article cites 63 articles, 19 of which can be accessed free at:

http://genesdev.cshlp.org/content/7/5/812.full.html\#ref-list-1

License

Email Alerting Receive free email alerts when new articles cite this article - sign up in the box at the Service top right corner of the article or click here.

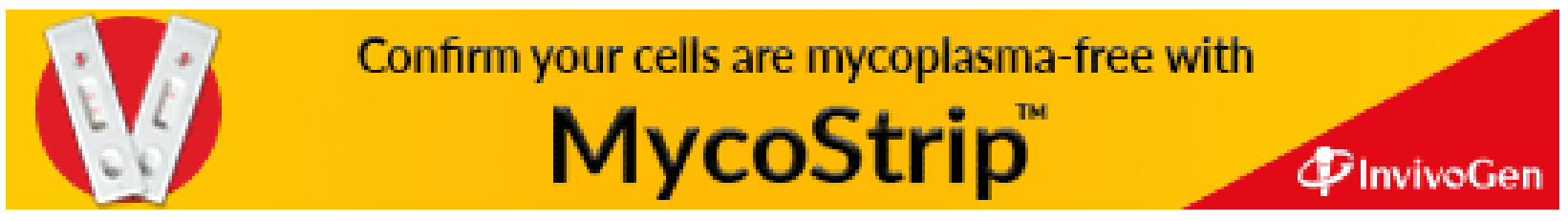

